\title{
Articles
}

Central European Review of Economics \& Finance

Vol. 18, No. 2(2017), pp. 31-48. D0I: 10.24136/ceref.2017.007

Renata Małkowska ${ }^{1}$

\section{PUBLIC FINANCE SECTORS CENTRAL AND EASTERN EUROPEAN COUNTRIES AND IN DEVELOPED COUNTRIES}

This paper analyses the interdependencies between state debt and the volume of the public sector's expenditure, focusing particularly on pro-social spending. These phenomena have been studied in relative values (versus GDP) and in absolute values (per capita). This served as the grounds for an attempt to identify general directions of the public finance policies followed by countries in the Central and Eastern Europe and in selected highly developed countries.

JEL Classification Codes: H5, H6.

Keywords: deficit, public expenditure, public sector, types of capitalism.

\section{Introduction}

The purpose of this paper is to identify interdependencies between the model of a state and the volume and structure of the public sector expenditure. The economic crisis which started with the financial crisis in 20072008 made it necessary to curb public spending, which, however, encountered growing resistance of extensive social groups in individual states. Additionally, historically motivated experiences of the anti-crisis and anticyclical policies were pointed at as, to a major extent, they involved increasing the public spending. To put it simply, it comes down to a dichotomous division into demand and supply methods of supporting social and economic

\footnotetext{
${ }^{1} \mathrm{PhD}$, Institute of Finance, Collegium of Management and Finance, Warsaw School of Economics.
} 
development. It, thus, becomes very important to observe actual processes taking place in this context in highly developed countries as this observation embodies a certain compromise between strengthening the state budget discipline and the requested public sector's involvement in counteracting crisis phenomena (Osiński, 2012; Kowalik, 2005). Observation of the dynamics of the budget deficit, the public debt, the volume and the structure of the public expenditure, when pursuing anti-crisis policies in individual countries, is of primary importance in terms of cognition and application. In particular, such an analysis may contribute to finding out whether CEE countries reveal similarities to highly developed states or whether they search for their own solutions to these issues. The first section of this paper comprises theoretical considerations, which serve as grounds for grouping the countries according to the criteria of development levels and the public sector's share in social and economic life. The second section of this paper analyses data related to highly developed countries and CEE states. This analysis covers the period starting from 2007, referred to as $2007+$. It is common knowledge that international comparisons directly depend on statistical systems following various rules in different states. Standardisation attempts have been made, for instance, by the OECD and EU. The set of data for OECD countries which the author is focusing on contains numerous gaps. Depending on the measures, information for various countries is available in incomplete time sequences and some of it, for some countries, is missing. This results from the differences in classification of even the basic economic categories. Thus, the analysis covers selected years of the 2007-2013 period, debt measures and public expenditure volumes for Austria, Belgium, the Czech Republic, Denmark, Estonia, Finland, France, Greece, Spain, the Netherlands, Ireland, Japan, Luxembourg, Latvia, Germany, Norway, Poland, Portugal, Slovakia, Slovenia, Switzerland, Sweden, USA, Hungary, the United Kingdom and Italy ${ }^{2}$.

\section{Contemporary Public Sector in Various System Models}

Attempts to resolve problems which are consequences, among others, of large economic discrepancies between countries, aging societies, migrations, growing unemployment rates consume great volumes of public funds, which then contributes to the growing public debt. Hence the continuous search for

\footnotetext{
${ }^{2}$ For Lithuania, Romania and Bulgaria - there is no information available comparable with the rest of the analysed countries, and therefore, they have not been taken into account in this paper.
} 
an optimal relation between active and liberal economic policies that would allow reaching stable, long-term economic development and at the same time, satisfy the needs of the part of society which for various reasons is not able to prosper in a market economy environment (Buchanan, Musgrave, 2005). The European Union member countries most often implement the welfare state model.

The importance of public finance to the economy is growing along with the growing activity of the state when interfering with the market economy. One may offer three groups of countries as examples here. The extreme form was employed by countries of the real socialism while the other extreme was represented by South American countries, where the role of the state was constrained as much as possible leading to significant social stratification. Japan, which applied a balanced model of cooperation between the state and "the invisible hand of the market", is an example of a country where the free market is supported by state actions.

According to representatives of theories referring to A. Smith, execution of both these functions by the state contributes to greater destabilisation of the economy, which impairs effective use of available resources. The tinderbox is what the supporters of both directions regard as economically and socially rational distribution of income (Zalewski, 2007, p. 11).

Changing external conditions force the evolution of economic and social systems. Individual states undergo transformation processes, including those in Central and Eastern Europe. Still none of them has an ideal solution that would meet all the people's expectations about the role of state in the social and economic life, meaning a solution that would make the state interfere with the market mechanisms the least and, at the same time, fully protect the weakest members of the society - „distributive justice” (Leon XIII, 1892, pp. 121-123). The model most frequently present in highly developed countries is the social market economy, where attribution of the top priority to free market does not eliminate, but still limits the welfare role of the state.

Most generally, one may conclude that the basic problem in the functioning of contemporary societies, particularly the highly developed ones, is the failure to balance broadly defined income and expenditure of the public finance sector. The spending of this sector results from the necessity to finance two groups of needs, which in specific situations are found justified, namely: securing the state's functioning in four basic areas and supporting as well as correcting social-economic processes, which make up the essence of the social and economic life in a given country (Malinowska, Misiąg, 2007, pp. 14-19). The extent to which the needs in both these spheres are satis- 
fied may be - and in practice, is - very diverse, depending on the adopted and socially accepted model of the state. Differences are so significant here that they are the starting point for creating separate typologies of countries within the capitalist system. The grounds are always certain features of functioning of the systems being analysed - ones that are regarded as the most important in terms of their influence on the course of social-economic processes. One may notice that, to a great extent, regardless of the detailed constructions of the catalogue of the basic criteria for classifying the forms of the capitalist system observed in practice, analysts - in general terms obtain similar results of their studies. They reveal domination of: the liberal model in Anglo-Saxon countries, the interventionist model in North, Central and Eastern Europe, the intermediate model in Mediterranean countries and another type of custom models in Asian and South American countries. In the literature one may find (Gładys-Jakóbik, 2012, pp. 45-52):

- Comparisons based on observations of the range of state interventions in five spheres: industrial manufacture, education, including learning an occupation, corporate governance, relations between businesses and relations between employees. Categorisation of states carried out on this basis leads to the location of the analysed system between two extreme models: the market economy based on coordination and the liberal economy. As a result the Authors point to the following groups: four countries with liberal economies (USA, the United Kingdom, Australia, Canada, New Zealand, Ireland), ten countries with a high level of coordination processes (Germany, Japan, Switzerland, the Netherlands, Belgium, Sweden, Norway, Denmark, Finland, Austria) and six states of the Mediterranean model (France, Italy, Spain, Portugal, Greece, Turkey) (Hall, Soskice, 2001).

- Comparisons based on the analysis of 5 areas: the product-market competition, the wage-labour nexus and labour-market institutions, the financial intermediation sector and corporate governance, the range of social protection and the welfare state, the functioning of the education sector. Application of these criteria results in identification of five state models of contemporary capitalism: market-based model (the United Kingdom, USA, Australia, New Zealand, Ireland), social-democratic model (Sweden, Norway, Denmark), the Continental European model (France, Germany, the Netherlands, Austria), the Mediterranean model (Italy, Spain, Greece), the Asian model (Japan, South Korea) (Amable, 2009, p. 17).

- Comparisons taking into consideration the main non-economic, cultural features, including: everyday life, the role of gainful employment, perception of groups with capital, employee management, the negotiation man- 
ner, were the grounds for defining conditions for the functioning of the social-economic development component, regarded as the most important, that is the innovative company (Hamptden-Turner, Trompenaars, 1998, p. 15). Systems which differ but still constitute models of social and economic development are those in the following seven countries: the United States, the United Kingdom, Sweden, France, Japan, the Netherlands, and Germany.

It is worth pointing out that the CEE countries cannot be easily classified into any of the abovementioned groups. One of the reasons is the diversity of the post-socialist states, both in terms of economy, institutions, cultures, pursued social policies etc. (Myant, Drahokoupil, 2011, pp. 301-302). Making homogenous assumptions for this part of Europe by definition impairs the quality of the results, independent of the applied taxonomies (Maszczyk, 2015, pp. 116-117). Additionally, it is hard to classify countries which are continuously undergoing reforms (significant from the perspective of criterion selection). Although the first stage of the transformation has been completed, the post-socialist states are still evolving and are searching for their own paths of development. Perhaps, thanks to their integration with the EU, this may be the model somehow similar to one (or several ones) already present in the Union (Rapacki, Próchniak, 2010, p. 525).

It is worth adding that the studies carried out in this area demonstrate that the majority of the CEE states are going towards the Mediterranean model, with the exception of Estonia, which is classified into the group of states with the Anglo-Saxon model of capitalism (Zielenkiewicz, 2013, p. 386).

\section{Public Sector after 2007 Crisis in Highly Developed and CEE Countries}

When analysing the size of the public sectors in 2007-2013 in selected highly developed countries and in CEE states, 18 measures were taken into consideration (Moździerz, 2009, p. 97; Ebbinghaus, 2012), including:

- measures showing the relative value of the public debt and deficit,

- the fiscalisation ratio understood as the value of income of the central and local government institutions' sector as \% of GDP and the socialisation ratio understood as the value of spending of central and local government institutions' sector to GDP, 
- the structure of expenditure of the central and local government institutions according to functions (\% of total) ${ }^{3}$,

- the structure of expenditure of the central and local government institutions' sector split by expenditures of the central government, local governments and social security sectors.

The ratio of the budget deficit or surplus and, in some way, the derivative of these values in the long run, i.e. the value of the public debt calculated as the portion of GDP are the basic measures of evaluation of the public finance sector.

In 2007-2013, out of 26 examined countries, budget deficit in the central and local government institutions' sector was present: in 2007 in 14 countries, in 2008 in 18 countries, in 2009 in 24 countries. In 2010-2013 the deficit was present in 22 countries (during that period budget surplus was continuously reported in Norway and Switzerland only, while Estonia, Sweden, Luxembourg and Germany occasionally appeared in this group).

In 2007 budget surplus was reported in 12 countries - the highest surplus was found in Norway (17.1\% of GDP), Finland (5.1\% of GDP) and Denmark (5.0\% of GDP). In 2007 the highest state budget deficit was observed in: Greece (-6.8\% of GDP), Hungary (-5.1\% of GDP), the USA (-3.6\% of GDP), Portugal and the United Kingdom (-3.0\% of GDP). In 2013 state budget surplus was generated only in 4 countries: Norway (11.3\% of GDP), Luxembourg ( $0.9 \%$ of GDP), Germany ( $0.2 \%$ of GDP), Switzerland ( $0.1 \%$ of GDP), while the highest deficit was in 2013 present in: Slovenia (-14.6\% of GDP), Greece (-12.3\% of GDP), Japan (-8.5\% of GDP), Spain (-6.8\% of GDP), Ireland (-5.8\% of GDP), the United Kingdom (-5.7\% of GDP) and the USA (-5.6\% of GDP).

In 2007-2009 the number of countries generating budget deficit grew up and the deficit levels among the countries with the top deficit values increased. This seems to be related not only to Wagner's law of continuously growing state spending but also a consequence of the global financial crisis (Łaski, 2011, p. 11; Ziółkowska, 2015, pp. 589-592). Aid programs of various nature, although they are to contribute to the stabilisation of financial systems, cause the deficits to grow. Loans taken are largely allocated to handle the current debt and increase indebtedness in the future. Only "healthy economies" may spend funds acquired in this manner on pro-development projects and overcoming the recession. Weaker economies, which use this

\footnotetext{
${ }^{3}$ Ten ratios demonstrating the structure of expenditure of the central and local government institutions classified according to COFOG - Statystyka sektora instytucji rządowych i samorządowych, GUS, Warszawa 2010, pp. 198-200.
} 


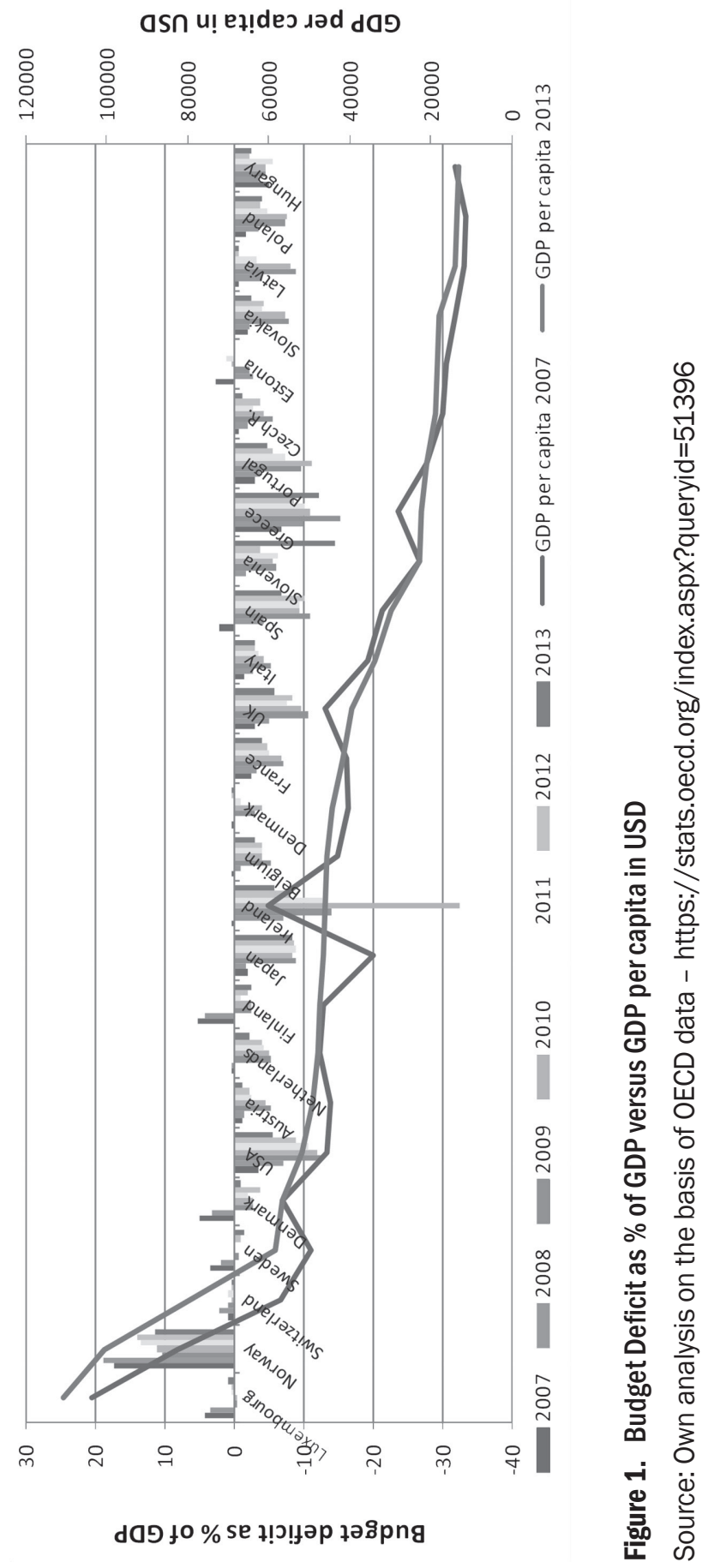


type of assistance, become more and more dependent on it (Rzońca, 2008, pp. 14-16). In 2010-2013 the number of countries with deficit stabilised. Further, this phenomenon was accompanied by decreasing deficit values. CEE countries, in terms of budget deficit to GDP, found themselves among states with medium values of this measure (with Slovenia being a negative exception and Estonia - a positive one).

In 2007 the top values of the public debt were reported in: Japan (180\% of GDP), Greece (112.8\% of GDP), Italy (110.6\% of GDP), Belgium (93.5\% of GDP), while the lowest in: Estonia (7.3\% of GDP), Luxembourg (11.9\% of GDP), Latvia (12.8\% of GDP), Ireland (27.5\% of GDP), Slovenia (29.1\% of GDP). In 2013 the highest public debt levels were observed in: Japan (239.3\% of GDP), Greece (179.7\% of GDP), Italy (143.0\% of GDP), Portugal (141.2\% of GDP), Ireland (136.6\% of GDP), while the lowest in: Estonia (13.5\% of GDP), Luxembourg (30.1\% of GDP), Norway (34.8\% of GDP), Latvia (42.6\% of GDP), Sweden (44.6\% of GDP).

As may be noticed from 2007 to 2013 , particularly in the countries with poorest results, there was a vivid increase of the public debt from 100-180\% up to $140-200 \%$ of GDP. Among the best ones, the situation also deteriorated because the public debt in this group increased from levels of $10-30 \%$ up to $30-50 \%$ of GDP. As regards the public debt, the CEE countries found themselves among those analysed states with the lowest values (with Hungary as a negative exception).

Thematic Maps no. 1 and 2 (figure 2) present the spatial distribution, in the same ranges of colours and classes, of relative values of central and local government institutions' debt in 2007 and 2013, respectively. The applied analysis method has brought interesting results here. One may, first of all, notice a process of spectacular increase of relative values of public debt in OECD member states between 2007 and 2013. It also turns out that this growth was not only observed in South European countries (Greece, Italy, Portugal, Spain) but also Ireland, France and the United Kingdom. Clearly lower debts were observed in the countries of Central Europe (Hungary, Austria, Slovenia, Germany). The mildest growth of relative and, consequently, the lowest debts were observed in post-communist countries (Poland, Slovakia, the Czech Republic, Latvia, Estonia) and in the Scandinavian countries. Thematic Map no. 2 is virtually a model presentation of "three geographic zones" representing three groups of countries, which clearly demonstrates "diversities" of Europe in terms of relative debt values of central and local government institutions. 


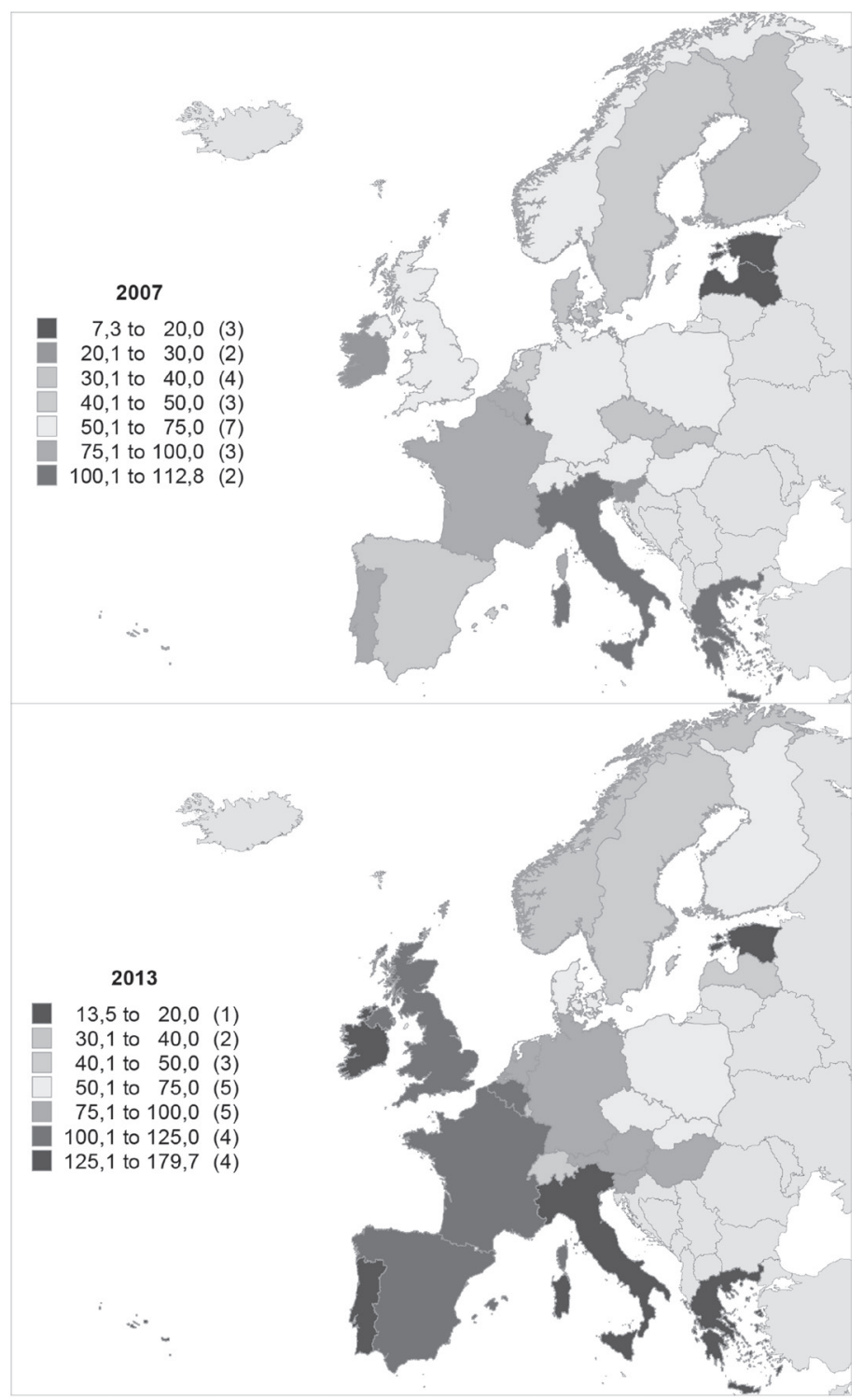

Figure 2. Thematic Maps no. 1 and no. 2: Gross Public Debt of Central and Local Government Institution's Sector as \% of GDP in 2007 and 2013

Source: Own analysis on the basis of OECD database - https://stats.oecd.org/index. aspx?queryid=51396. The map does not include the USA and Japan with values of 63.1 and 180.0 as well as 102.7 and 239.3 in 2007 and 2013, respectively, which means they fall into high public debt ranges; additionally, for 2013 due to the lack of data for Switzerland, the 2012 debt value of $45.7 \%$ was taken for the analysis. 


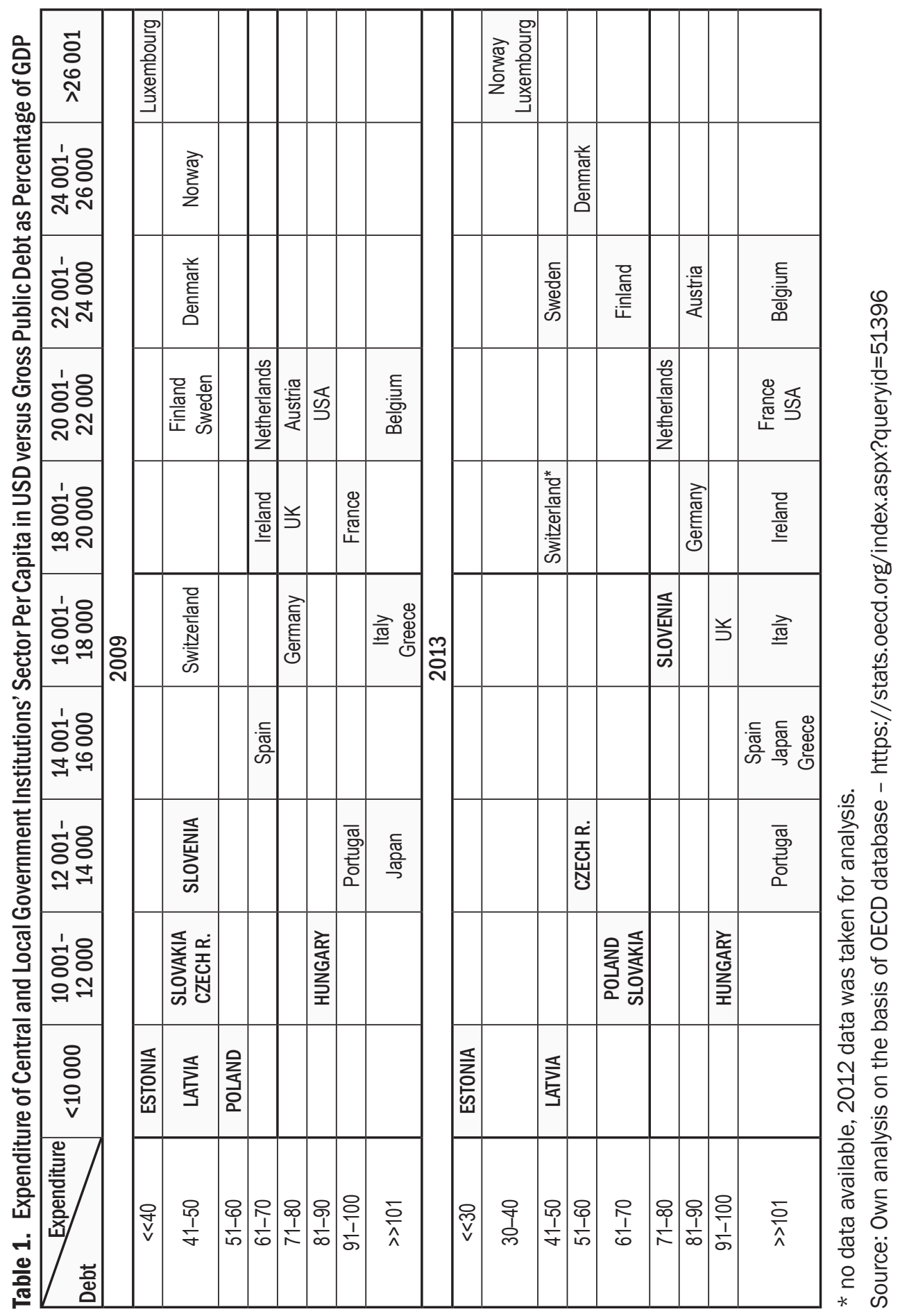


Paradoxically, the "healthiest” public finance systems were observed in the Central and Eastern Europe countries.

What is characteristic is the fact that in 2013 the debt is weakened "going" along the south-west axis (Portugal, Spain) towards north-west (Finland, Sweden, Estonia, Latvia - compare Thematic Map no. 2).

What deserves special attention is the measures which show deficit and public debt values observed at the beginning of the crisis (in 2007) and in 2013 (the last year for which fairly complete data are available) - compare Table 1.

Separate examinations of the public debt and of the public spending to describe the condition of the public sector in individual countries do not provide a true picture of the situation. Thus, Table 1 presents correlations of the public debt as percentage of GDP and the public spending per capita in USD. Such comparisons have been prepared for 2009 and $2013^{4}$. The presented data allow formulation of the following facts:

- between 2009 and 2013, in the group of the analysed countries, there was an increase of the public debt (in 2009 the public debt of over $80 \%$ of GDP was observed in 8 and in 2013 - in 13 countries out of 26 under examination);

- a relatively high level of public debt is not an obstacle for increasing public expenditure in the most developed countries (in 2009 the highest expenditure and the highest relative debt levels were observed in France, the USA and Belgium, while in 2013 - that was additionally Germany, Ireland and Austria);

- among the examined countries, both in 2009 and 2013, all the examined EU member states from Central and Eastern Europe (Estonia, Latvia, Poland, Slovakia, the Czech Republic, Slovenia) invariably demonstrated the lowest public debt versus GDP and the lowest public expenditure per capita in USD. Hungary diverged from that group to a narrow extent. This situation proves those countries maintained public expenditure discipline despite having the lowest spending among the examined countries calculated in absolute values per capita.

Tasks directly or indirectly accomplished by the public sector institutions must be directly reflected in the volumes and structure of public expenditure. Fairly advanced are attempts to identify - through indication and precise definition - financial investments, which define the scope of the state's func-

\footnotetext{
${ }^{4}$ The choice of years (just like in Table 2 ) has been dictated by the availability of fairly complete statistical data.
} 
tions. This is supported by COFOG $^{5}$ developed within the System of National Accounts, or SNA. Such classification has a number of potential strengths, however, its consistent application is difficult even to single countries and satisfactory comparability between countries and comparability in time are also hardly achievable. This particularly applies to the structure of public income and spending in individual countries. Despite the missing items, Classification of the Functions of Government, or COFOG, allows making comparisons in time and between countries. On the basis of recurring analyses one may observe that within different „types" of social-economic states in the EU (both highly developed and post-communist countries) there is a similar share of consolidated investments ${ }^{6}$ of the central and local government institutions versus GDP.

Thematic Maps no. 3 and no. 4 (Figure 3) present, in the same ranges of colours and classes, relative values of central and local government institutions' spending as percentage of GDP in 2007 and 2013. When comparing both maps it is clearly visible that during the $2007+$ crisis, the level of spending of the discussed group measured in this manner quite significantly increased in nearly all of the analysed OECD member states. Both in 2007 and 2013, relatively lowest expenditures were observed in CEE countries. It must be particularly stressed that unlike the definite majority of the countries under examination, relative values of public spending in Poland and Hungary dropped between 2007 and 2013.

Observation of the levels of fiscalisation and socialisation of the economy, expressed as the ratio of income and spending of the discussed sector to GDP, does not allow defining the real level of this spending. Therefore, Table 2, separately for 2009 and 2013, correlates the government expenditure per capita in USD with this sector's intensified involvement in the sphere of direct expenditures of the "social" nature. Such expenditures include seven out of ten COFOG groups of functional spending, namely spending on: environmental protection; housing and community amenities; health; recreation culture and religion; education; and social protection. For each of the analysed ratios, all the examined countries were divided into three groups by a given measure, i.e. the maximum, the average and the minimum. The maximum level was assigned weight 2 , the average - weight 1 , and the

\footnotetext{
${ }^{5}$ Classification of the Functions of Government.

${ }^{6}$ "Consolidated investments of the central and local government institutions" represent the net sum of expenditures and purchases of non-financial assets after eliminating intra- and inter-institutional transfers.
} 
minimum - weight 0 . In this ranking method the rank values were summed up for each of the examined countries. This defined the „pro-social” profile of the public sector's spending and helped arrange them from the highest to the lowest involvement of public expenditure in the social sphere. The resulting hierarchical layout of the countries was correlated in a matrix with the spending of central and local government institutions' presented in USD per capita. This led to the estimation of public „pro-social spending” in the analysed countries.

When comparing data in Table 2 for the years of 2009 and 2013 one may see lower intensity of „pro-social spending” - in 2009 low involvement in this expenditure group (ranks 3-6) was observed in 8 countries, while in 2013 (ranks 2-6) - in 14 countries. It must, however, be stressed that among the countries analysed here there are greater than twofold differences in the expenditure of the sector counted in USD per capita. Thus both in 2009 and 2013 this type of expenditures by „rich" and "less affluent” countries are not similar despite the fact that both these groups demonstrated similar shares of "pro-social spending” in the public sector's total spending. In particular, one must point out that CEE countries (Estonia, Latvia, Poland, Slovakia, Hungary, the Czech Republic, reporting average involvement in „pro-social spending", spend 1.5 to 2 times less per capita than the highly developed countries.

When analysing the abovementioned different involvements of investment groups of the discussed sector versus GDP generated in individual countries, one must remember that these differences are multiplied by disproportions in per capita GDP in the analysed objects. 


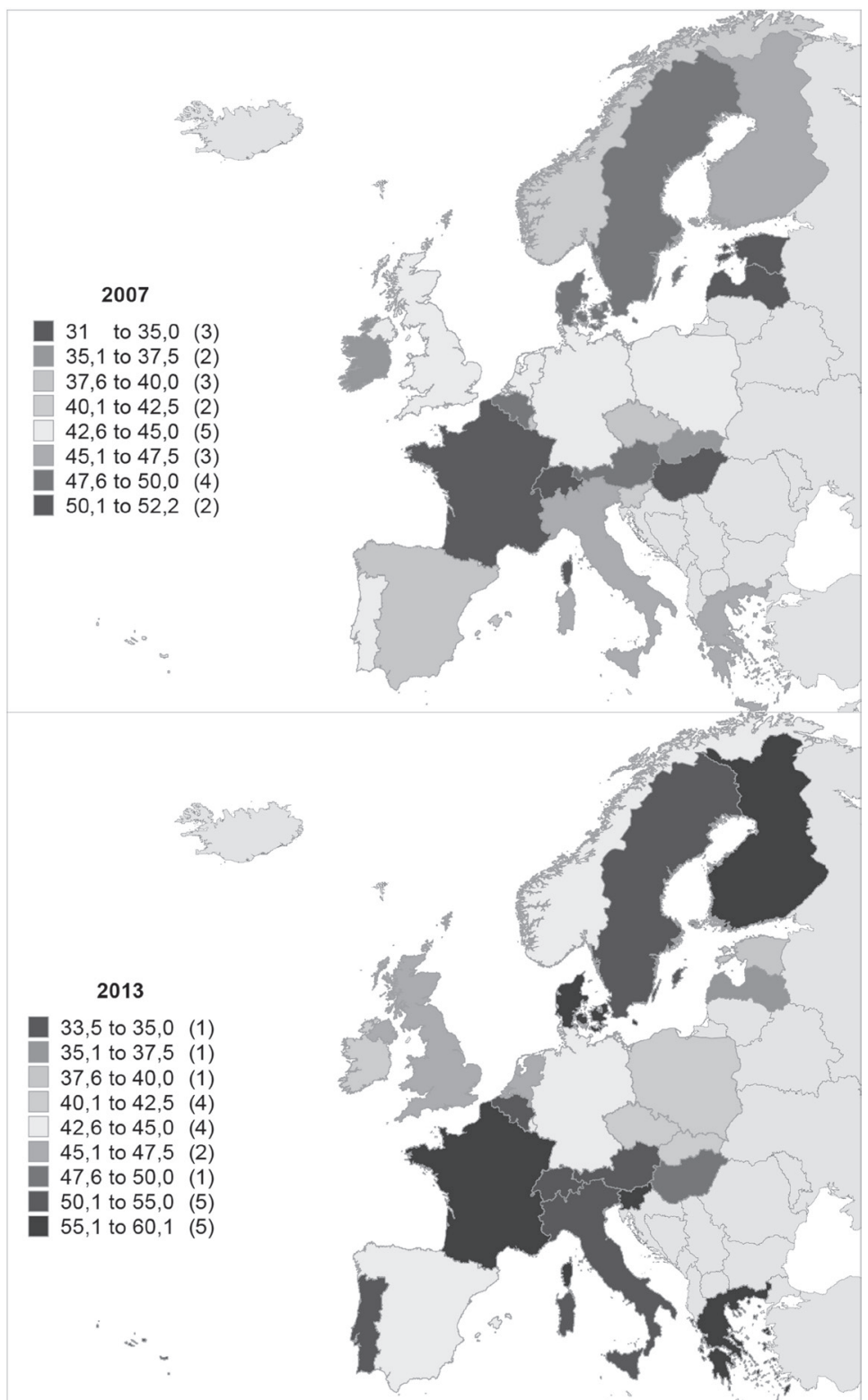

Figure 3. Thematic Map no. 3 and no. 4: Expenditures of Central and Local Government Institutions as \% of GDP in 2007 and 2013

Source: Own analysis on the basis of OECD database - https://stats.oecd.org/index. aspx?queryid=51396. The map does not include the USA and Japan with values of 36.9 as well as 35.8 and 38.7 as well as 42.3 in 2007 and 2013, respectively - which means that they fall into low spending ranges. 


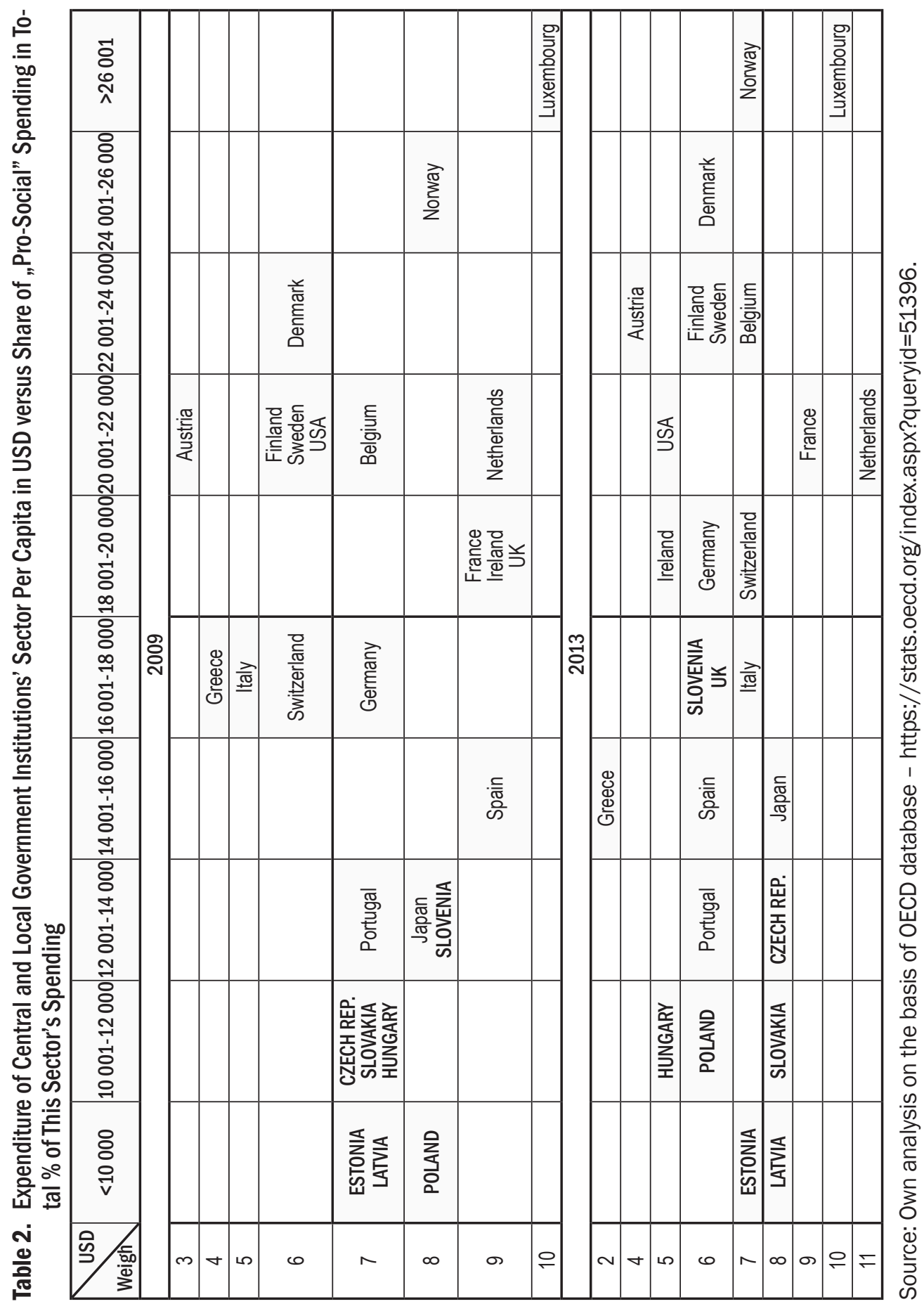




\section{Conclusions}

The countries which after the year 1989 transformed, built their economic, social and financial systems, followed recommendations of international financial institutions, including those functioning within the EU. These recommendations turn out to have been and still are, in majority of cases, followed in practice, which is not the case in highly developed countries. Paradoxically, post-communist countries in most cases, compared to "affluent” countries of Western Europe, maintain public finance discipline and stabilise or even limit their spending to curb their debts.

The summary must also contain the following conclusions:

- the 2007+ Crisis increased expenditure of the central and local government institutions. This took place particularly in highly developed EU states, not only those undergoing structural difficulties (Spain, Greece or Ireland);

- the public sectors in Central and Eastern European countries, despite keeping their spending at an average level versus GDP, actually spend 2-3 times less than those in highly developed countries with high GDP values, which indirectly translates there into high public expenditure per capita in USD.

Following the analysis one may distinguish three groups - South European countries (Greece, Spain, Italy, Portugal) suffering from structural difficulties in the public finance area. Similar debt values are observed in highly developed, relatively "healthy” economies like France, Germany, the United Kingdom, the Benelux countries. Most of them have high levels of public debt and high relative and absolute levels of public spending. A separate group is here formed by "new” members of the European Union: Poland, the Czech Republic, Latvia, Estonia, Hungary, Slovakia, Slovenia, which have relatively low levels of public debt, average-low levels of public expenditure, while in terms of per capita values definitely stand out among the rest of the EU highly developed countries. In this group of countries one may hardly identify similar behaviours compared to two previously mentioned groups of highly developed countries. 


\section{References}

Amable B. (2009). Structural reforms In Europe and the In coherence of institutions, Oxford Review of Economic Policy No. 1. Vol. 25.

Buchanan J.M, Musgrave R.A. (2005). Finanse publiczne a wybór publiczny. Dwie odmienne wizje państwa, Sejmowe, Warszawa.

Bukowski S. and Gowers R. (2016). The degree of integration of equity markets in Central Europe (new member EU countries) with the US and UK equity markets, Central European Review of Economics \& Finance No. 1, Vol. 11.

Drahokoupil J., Myant M. (2011). Transition Economies: Political Economy In Russia, Eastern Europe and Central Asia, John Wiley\&Sons, Glasgow.

Ebbinghaus B. (2012, wrzesień). Comparing Welfare State Regimes: Are Typologies an Ideal or Realistic Strategy? European Social Policy Analysis Network, ESPAnet Conference, Edinburgh.

Gładys-Jakóbik J. (2012). Kryzys kapitalizmu wartości etycznych czy współczesnej kultury? [In:] J. Osiński (ed.), Kapitalizm czy kapitalizmy? Anatomia i ewolucja formacji, OW SGH Warszawa.

Hall P.A., Soskice D.W. (2001). Varietes of capitalism. The institutional foundations of comparative advantage, Oxford University Press, Oxford.

Hamptden-Turner Ch., Trompenaars A. (1998). Siedem kultur kapitalizmu, Dom Wydawniczy ABC, Warszawa.

GUS (2010). Statystyka sektora instytucji rządowych i samorządowych. Warszawa.

Jan Paweł II (1991). Centesimus Annus, Wydawnictwo Wrocławskiej Księgarni Archidiecezjalnej, Wrocław.

Kowalik T. (2005). Systemy gospodarcze. Efekty i defekty reform i zmian ustrojowych, Fundacja Innowacja, Warszawa.

Łaski K. (2011). Strukturalne przyczyny kryzysu finansów publicznych w Unii Europejskiej, Studia Ekonomiczne nr 1 (LXVIII).

Leon XIII (1892). Enc. Rerum novarum, Leonis XIII P. M. Acta, XI, Rzym.

Malinowska E., Misiąg W. (2007). Finanse w Polsce, Wydawnictwo Prawnicze LexisNexis, Warszawa.

Maszczyk P. (2015). Ewolucja modelu kapitalizmu w Polsce, Nierówności Społeczne a Wzrost Gospodarczy, nr 41(1).

Molendowski E. (2015). 10 Years of Membership in the European Union Poland in Comparison with the Visegrad Group countries, Central European Review of Economics \& Finance No. 4, Vol. 10. 
Moździerz A. (2009). Nierównowaga finansów publicznych, PWE, Warszawa.

Rapacki R., Próchniak M. (2010). Wpływ rozszerzenia Unii Europejskiej na wzrost gospodarczy i realną konwergencję krajów Europy ŚrodkowoWschodniej, Ekonomista nr 4.

Rzońca A. (2008). Paraliżujący deficyt, Seria: Zeszyty FOR, Fundacja Forum Obywatelskiego Rozwoju, Warszawa.

Zalewski A. (2007). Reformy sektora publicznego w duchu nowego zarządzania publicznego, [In:] Zalewski A. (red.), Nowe zarządzanie publiczne w polskim samorządzie terytorialnym (s. 11-73). Warszawa: OW SGH.

Zielenkiewicz M. (2013). Miejsce krajów Europy Środkowej i Wschodniej we współczesnych modelach kapitalizmu, Przegląd Zachodniopomorski. Rozprawy i Studia, Tom XXVIII (LVII), zeszyt 3, vol.2.

Ziółkowska W. (2015). Kontrowersje wokół długu sektora general government w krajach Europy Środkowej i Wschodniej w kontekście ostatniego kryzysu, [In:] Ostaszewski J. (ed.), O nowy ład finansowy w Polsce. Rekomendacje dla animatorów życia gospodarczego, OW SGH, Warszawa. 